\title{
Effects of daily 24-gram doses of rice or whey protein on resistance training adaptations in trained males
}

\author{
Jessica M. Moon ${ }^{1}$ D, Kayla M. Ratliff', Julia C. Blumkaitis', Patrick S. Harty² ${ }^{\mathbb{D}}$, Hannah A. Zabriskie ${ }^{3}$,
}

Richard A. Stecker ${ }^{1}$, Brad S. Currier ${ }^{1}$, Andrew R. Jagim ${ }^{4}$ (D) Ralf Jäger ${ }^{5}$ (D) Martin Purpura ${ }^{5}$ and Chad M. Kerksick ${ }^{1 *}$ (D)

\begin{abstract}
Background: Large (48-g), isonitrogenous doses of rice and whey protein have previously been shown to stimulate similar adaptations to resistance training, but the impact of consuming smaller doses has yet to be compared. We evaluated the ability of 24-g doses of rice or whey protein concentrate to augment adaptations following 8 weeks of resistance training.

Methods: Healthy resistance-trained males $\left(n=24,32.8 \pm 6.7\right.$ years, $179.3 \pm 8.5 \mathrm{~cm}, 87.4 \pm 8.5 \mathrm{~kg}, 27.2 \pm 1.9 \mathrm{~kg} / \mathrm{m}^{2}, 27.8 \pm$ $6.0 \%$ fat) were randomly assigned and matched according to fat-free mass to consume $24-\mathrm{g}$ doses of rice $(n=12$, Growing Naturals, LLC) or whey ( $n=12$, NutraBio Labs, Inc.) protein concentrate for 8 weeks while completing a standardized resistance training program. Body composition (DXA), muscular strength (one-repetition maximum [1RM]) and endurance (repetitions to fatigue [RTF] at 80\% 1RM) using bench press (BP) and leg press (LP) exercises along with anaerobic capacity (Wingate) were assessed before and after the intervention. Subjects were asked to maintain regular dietary habits and record dietary intake every 2 weeks. Outcomes were assessed using $2 \times 2$ mixed (group $x$ time) factorial ANOVA with repeated measures on time and independent samples t-tests using the change scores from baseline. A p-value of 0.05 and 95\% confidence intervals on the changes between groups were used to determine outcomes.
\end{abstract}

Results: No baseline differences ( $p>0.05$ ) were found for key body composition and performance outcomes. No changes $(p>0.05)$ in dietary status occurred within or between groups $(34 \pm 4 \mathrm{kcal} / \mathrm{kg} / \mathrm{day}, 3.7 \pm 0.77 \mathrm{~g} / \mathrm{kg} / \mathrm{day}, 1.31 \pm$ $0.28 \mathrm{~g} / \mathrm{kg} /$ day, $1.87 \pm 0.23 \mathrm{~g} / \mathrm{kg} /$ day) throughout the study for daily relative energy (34 $\pm 4 \mathrm{kcals} / \mathrm{kg} / \mathrm{day}$ ), carbohydrate $(3.7 \pm 0.77 \mathrm{~g} / \mathrm{kg} /$ day $)$, fat $(1.31 \pm 0.28 \mathrm{~g} / \mathrm{kg} /$ day $)$, and protein $(1.87 \pm 0.23 \mathrm{~g} / \mathrm{kg} /$ day $)$ intake. Significant main effects for time were revealed for body mass $(p=0.02)$, total body water $(p=0.01)$, lean mass $(p=0.008)$, fat-free mass $(p=0.007)$, $\operatorname{BP} 1 \mathrm{RM}(p=0.02)$, BP volume ( $p=0.04)$, and LP 1RM $(p=0.01)$. Changes between groups were similar for body mass $(-0.88,2.03 \mathrm{~kg}, p=0.42)$, fat-free mass $(-0.68,1.99 \mathrm{~kg}, p=0.32)$, lean mass $(-0.73,1.91 \mathrm{~kg}, p=0.37)$, fat mass $(-0.48$, $1.02 \mathrm{~kg}, p=0.46)$, and $\%$ fat $(-0.63,0.71 \%, p=0.90)$. No significant between group differences were seen for BP $1 \mathrm{RM}$ $(-13.8,7.1 \mathrm{~kg}, p=0.51)$, LP 1RM $(-38.8,49.6 \mathrm{~kg}, p=0.80)$, BP RTF $(-2.02,0.35$ reps, $p=0.16)$, LP RTF $(-1.7,3.3$ reps, $p=$ $0.50)$, and Wingate peak power $(-72.5,53.4$ watts, $p=0.76)$ following the eight-week supplementation period.

(Continued on next page)

\footnotetext{
* Correspondence: ckerksick@lindenwood.edu

${ }^{1}$ Exercise and Performance Nutrition Laboratory, School of Health Sciences, Lindenwood University, 209 S. Kingshighway, St. Charles, MO 63301, USA

Full list of author information is available at the end of the article
}

\section{$\triangle B M C$}

(c) The Author(s). 2020 Open Access This article is licensed under a Creative Commons Attribution 4.0 International License, which permits use, sharing, adaptation, distribution and reproduction in any medium or format, as long as you give appropriate credit to the original author(s) and the source, provide a link to the Creative Commons licence, and indicate if changes were made. The images or other third party material in this article are included in the article's Creative Commons licence, unless indicated otherwise in a credit line to the material. If material is not included in the article's Creative Commons licence and your intended use is not permitted by statutory regulation or exceeds the permitted use, you will need to obtain permission directly from the copyright holder. To view a copy of this licence, visit http://creativecommons.org/licenses/by/4.0/ The Creative Commons Public Domain Dedication waiver (http://creativecommons.org/publicdomain/zero/1.0/) applies to the data made available in this article, unless otherwise stated in a credit line to the data. 
(Continued from previous page)

Conclusions: Eight weeks of daily isonitrogenous 24-g doses of rice or whey protein in combination with an eightweek resistance training program led to similar changes in body composition and performance outcomes. Retroactively registered on as NCT04411173.

Keywords: Protein source, Supplementation, Rice, Whey, Plant proteins, Protein isolates, Fat-free mass, Body composition, Strength, Endurance, Performance, Efficacy

\section{Background}

Recommended protein intake levels to meet the requirements of nearly all healthy adults are set at $0.8 \mathrm{~g}$ of protein per kilogram of body mass per day [1]. However, professional organizations such as the American College of Sports Medicine (ACSM) and International Society of Sports Nutrition (ISSN) recommend that exercising adults should consume higher amounts of daily protein $[2,3]$. In response to exercise and in the absence of feeding, rates of muscle protein synthesis (MPS) and muscle protein breakdown both increase with the overall net muscle protein balance remaining negative [4]. However, the acute consumption of an efficacious dose (i.e., $0.25-0.35 \mathrm{~g} / \mathrm{kg} / \mathrm{dose}$ ) of high-quality protein has been consistently shown to stimulate rates of MPS leading to a positive net muscle protein balance [4-6]. The establishment of a positive net muscle protein balance through exercise and high-quality protein ingestion supports many exercise and nutrition strategies employed by individuals who wish to improve their body composition and/or increase their fat-free mass $[5,6]$.

Several protein sources derived from either animal (e.g., whey, casein, egg, beef, fish) or plant (e.g., soy, rice, pea, hemp) origins are available for individuals to consume and meet their daily protein needs. Assessments of protein quality routinely rate various protein sources based upon the amount and distribution of the essential amino acids, which are required for consumption in the diet and are known to operate as prerequisites for maximal stimulation of MPS [7, 8]. Protein sources can be further evaluated based upon their digestibility, bioavailability, rate of amino acid appearance, and relative amount of any given individual amino acid. Proteins are also characterized by more general health-related factors such as the presence of allergens, cholesterol, or saturated fat $[3,6]$. Due to differing amino acid profiles, many different types of animal proteins, particularly milk proteins (whey and casein) rank high on these rating scales, while various plant proteins that have lower amounts of one or more of the essential amino acids routinely rank lower [9]. Specifically, leucine content has become commonly accepted as an additional means by which the quality of a protein can be assessed, since previous work has indicated leucine may exert an independent influence over the promotion of a positive nitrogen balance and stimulation of MPS [10, 11]. In particular, leucine in doses ranging from $1.7-3.5 \mathrm{~g}$ may be needed to optimally promote MPS $[3,6]$. Therefore, the leucine content of varying protein sources has become a relevant consideration when choosing food-derived protein options that can go on to influence exercise training adaptations over time.

Previous work by Joy and colleagues [12] compared the effect of isonitrogenous doses of rice protein or whey protein on adaptations to resistance training, suggesting that both protein sources equally stimulated improvements in strength, performance, and fat-free mass [12]. While intriguing, these results lack ecological validity due to the large protein dose provided ( $48 \mathrm{~g}$ ), which is substantially larger than typical 'per serving' doses ingested by consumers or those recommended in the scientific literature $[3,5,6,13,14]$, notwithstanding recent work in nighttime protein feedings $[15,16]$. Other research by Purpura et al. [17] compared the rate and magnitude of amino acid appearance after ingesting a single 48-g dose of a rice or whey protein isolate. Whey protein isolate stimulated a faster peak concentration of the essential amino acids, nonessential amino acids, and total amino acids. When total area under the curve was computed over a four-hour measurement window, whey isolate was responsible for a $6.8 \%$ greater level of amino acids when compared to changes seen with rice protein isolate ingestion, a difference that was not statistically significant. Moreover, when the time to peak concentrations were identified between the two sources of protein, whey protein isolate resulted in faster appearance of most amino acids with the exception of leucine, whereas rice protein ingestion stimulated a faster time to peak leucine concentration in comparison to whey [17].

In considering these outcomes, additional research needs to be completed to identify the potential efficacy of ingesting smaller, more ecologically valid doses of rice protein while performing a heavy resistance training program. These findings will extend the previous results of Joy et al. [12] and also provide potential implications of the previous work of Purpura et al. [17]. Therefore, the purpose of this study was to compare the effect of isocaloric and isonitrogenous (24-g) doses of rice or whey protein concentrate $(\sim 80 \%$ protein $)$ on resistance training adaptations in young, healthy, resistance-trained men. It is hypothesized that there will be no differences 
in strength and body composition adaptations observed between study participants who supplement with rice or whey protein throughout the study protocol.

\section{Methods}

\section{Experimental design}

The study was conducted using a randomized, doubleblind approach where participants were matched into groups according to fat-free mass. Participants were provided 24-g doses of rice or whey protein concentrate for an eight-week supplementation period that coincided with completion of a linear periodized, split-body resistance training program consisting of two upper body and two lower body workouts each week. On workout days, one dose of supplemental protein was ingested within $60 \mathrm{~min}$ of workout completion. On non-workout days, one dose was ingested within $60 \mathrm{~min}$ of going to bed. A total of 10 weeks of resistance training were completed over the entire study protocol. The first 2 weeks of resistance training (eight workouts) occurred before supplementation began and were completed to acclimate participants to the program and to initiate early neurological adaptations commonly seen with starting a new resistance training program. After completion of this run-in period, participants then began the supplementation protocol and continued to follow the resistance training program for an additional 8 weeks. Consequently, a total of 40 workouts were assigned in this protocol. Before and after the resistance training and supplementation period, body mass, body water (total, extracellular, intracellular), and body composition (fat mass, fatfree mass, lean mass, and \% fat) were assessed. Changes in muscular strength (one-repetition maximum $[1 \mathrm{RM}]$ ) and muscular endurance (repetitions to fatigue at a load of $80 \%$ $1 R M,[R T F]$ ) were assessed using the bench press and leg press exercise, and Wingate anaerobic capacity tests were completed to assess anaerobic power. All anthropometric, body composition, and performance assessments were completed after 0,2 , and 10 of weeks of resistance training (Fig. 1). No supplementation occurred during the first 8 weeks of this protocol; consequently, all statistical analysis was completed on data collected starting at the beginning and end of supplementation. Participants were provided nutritional recommendations in order to ensure adequate energy ( $>30 \mathrm{kcal} / \mathrm{kg}$ body mass/day) and protein consumption $(>1.5 \mathrm{~g} / \mathrm{kg} /$ day $)$ to facilitate positive training adaptations and reduce the potential influence of differing dietary intakes $[3,18]$. Compliance cut-offs for removal for noncompliance were established at $90 \%$ compliance. This study was retroactively registered on clinicaltrials.gov as NCT04411173.

\section{Study participants}

Healthy, resistance-trained males $(n=24$, age: $32.8 \pm 6.7$ years, height: $179.3 \pm 8.5 \mathrm{~cm}$, weight: $87.4 \pm 8.5 \mathrm{~kg}$, body mass index: $27.2 \pm 1.9 \mathrm{~kg} / \mathrm{m}^{2}$, body fat \%, via DXA: $21.7 \pm 3.9 \%$ fat) participated in the study. To be eligible, participants reported at least 1 year of (self-reported) resistance training experience, could bench press $>1.0 \mathrm{x}$ their body weight, could leg press $>1.5 \mathrm{x}$ their body weight, and had a BMI less than $30 \mathrm{~kg} / \mathrm{m}^{2}$. If a participant's BMI was greater than $30 \mathrm{~kg} / \mathrm{m}^{2}$, they were accepted in the study if their body fat percentage (determined by DXA) was less than $30 \%$ body fat. Additionally, participants were required to stop taking all nutritional supplements except for multi-vitamins for 30 days before participating in the study and for the entire duration of the protocol.

\section{Anthropometric \& Resting Assessments}

Prior to all laboratory visits, participants fasted for at least 8 $\mathrm{h}$ and abstained from exercise, caffeine, nicotine, and alcohol for at least $24 \mathrm{~h}$. Upon arrival during the initial assessment, participant height was assessed to the nearest \pm 0.5 $\mathrm{cm}$ using an analog wall-mounted stadiometer (HR-200, Tanita Corp, Inc., Tokyo, Japan) with their shoes removed and standing erect on flat feet. Body mass was measured prior to all study visits using a self-calibrating digital balance (Tanita BWB-627A, Tokyo, Japan) and was recorded to the nearest $\pm 0.1 \mathrm{~kg}$. Additionally, body masses recorded after 0 and 2 weeks were compared to ensure the participants were weight stable. Any participant whose body mass deviated by more than $2 \%$ during this time was excluded from participation. Heart rate as well as systolic and diastolic blood pressure were assessed using an automatic blood pressure monitor (OMRON BP785, Omron Corporation, Kyoto, Japan). All hemodynamic measurements were completed in a supine position after the study participant had arrived in the laboratory and rested quietly on an exam table for approximately $10 \mathrm{~min}$. Participants were assessed for hydration status by providing a mid-flow urine sample analyzed by a handheld urine refractometer.

\section{Body composition}

Dual-energy X-ray absorptiometry Body composition was assessed using dual-energy $\mathrm{x}$-ray absorptiometry (DXA) (Hologic QDR Discovery A, Hologic, Inc., Bedford, MA, USA). A trained research assistant positioned all participants and manually analyzed all scans. Each day, the DXA was calibrated according to manufacturer recommendations and each scan was analyzed using the provided software (Hologic APEX Software, Version 4.5.3, Hologic Inc., Bedford, MA, USA) with the $\mathrm{Na}$ tional Health and Nutrition Examination Survey (NHAN ES) analysis approach employed. Fat-free mass, lean mass, fat mass, and body fat percentage were recorded. Test-retest reliability has been previously established for DXA fat mass (CV: 1.26\%, ICC: 0.99, SEM: $127.8 \mathrm{~g}$ ) and 


Body Mass $\begin{gathered}\text { Buy Food Record } \\ \text { 4rine sample/DEXA } \\ \text { Strength/Endurance }\end{gathered}$
TESTING
Wingate Anaerobic Capacity

DXA fat-free mass (CV: 0.75\%, ICC: 0.99, SEM: $110.9 \mathrm{~g}$ ) in cohort $(n=40)$ of healthy college-aged men and women.

Total body water Total body water (TBW) was assessed using bioelectrical impedance spectroscopy (SFB7, Impedimed Corp., Carlsbad, CA). Each participant's socks were removed to clean the dorsal surface of the foot and wrist prior to electrode placements. Two electrodes were placed on both the hand and foot. The proximal electrode for the foot was placed between the medial and lateral malleolus bones while the distal electrode was placed with the midpoint of the electrodes five $\mathrm{cm}$ apart. For the hand, researchers placed the proximal electrode on the midline of the ulnar styloid process with the distal electrode placed with the midpoints of the two electrodes spaced five $\mathrm{cm}$ apart. Once the electrodes were in place, researchers applied the four leads to their designated landmarks per manufacturer guidelines and researchers made certain the participants were not touching their sides and their legs were properly spaced apart. Three consecutive measurements were completed, averaged, and used for subsequent data analysis. TBW estimates produced by this unit have previously been validated against deuterium oxide dilution techniques in resistance-trained males [19]. Test-retest reliability has been previously established for bioelectrical impedance spectroscopy fat mass (CV: 5.86\%, ICC: 0.98, SEM: $280.9 \mathrm{~g}$ ) and fat-free mass (CV: $1.72 \%$, ICC: 0.99 , SEM:
$285.1 \mathrm{~g})$ in a cohort $(n=40)$ of healthy college-aged men and women.

\section{Performance assessments}

Maximal strength To assess changes in muscular strength throughout the study protocol, each participant's one-repetition maximum (1RM) was determined using the leg press and bench press exercises. Prior to 1RM determination, a standardized warm-up of simple stretches and whole-body movements spanning 5-10 min was completed. Using a protocol consistent with National Strength and Conditioning Association (NSCA) recommendations, participants completed one set of ten repetitions at $50 \%$ of their estimated 1RM. The warm-up continued in a progressive fashion (six repetitions at $70 \%$ of their perceived 1RM, four repetitions at $85 \%$ $1 \mathrm{RM}$, and one repetition at $95 \% 1 \mathrm{RM})$. Two minutes of rest were observed between each set. One-repetition sets were then completed with progressively increasing loads until a 1RM was determined. The 1RM for each exercise was determined within three to five one-repetition attempts and $2 \mathrm{~min}$ of rest were observed between each attempt. Post-testing 1RM assessment was completed using their previously established 1RM as a determinant for establishing loads throughout testing. Participants rested for $5 \mathrm{~min}$ between determination of their 1RM and completion of the next test. All leg press repetitions were completed using a commercial, 45-degree hip sled/ leg press machine. For all leg press activities, foot 
position and hip angle was standardized by recording the heel position throughout testing and using these parameters for future 1RM determinations. Participants were required to keep their hands free of their knees, thighs, and torso and lower the weight until the knee angle reached approximately 90 degrees of flexion. All bench press repetitions were completed using a standard adjustable bench press and knurled bar (Rogue Fitness, Columbus, $\mathrm{OH}$ ). Hand spacing was standardized for each attempt by recording the width of the hands for each repetition. In accordance with technique standards, participants were required to maintain five points of contact during all bench press repetitions and lower the bar to the sternum and press back until both elbows reached full extension. Two experienced research team members were present to ensure appropriate technique was maintained for both exercises throughout the testing.

Muscular endurance Approximately $5 \mathrm{~min}$ after each respective $1 \mathrm{RM}$ determination, study participants completed an upper and lower body muscular endurance assessment. These assessments were completed using a load that corresponded to $80 \%$ of their 1RM for both the leg press and bench press exercises. Participants were instructed to complete one set with as many repetitions as they could until failure and were required to maintain appropriate lifting technique throughout all repetitions while being supervised by a research team member. Full range of motion was required for all repetitions. The test was stopped and completed repetitions were counted if participants paused for greater than $2 \mathrm{~s}$ between repetitions or technique failure occurred throughout any repetition. Total training volume (sets $\mathrm{x}$ repetitions performed with $80 \% 1 \mathrm{RM} \times 80 \% 1 \mathrm{RM}$ load) for each exercise was computed and statistically analyzed. Further, data was normalized to one's body mass and entered for statistical analysis as both the raw and normalized data. Participants rested for $5 \mathrm{~min}$ between completion of their repetitions to failure and completion of the next test. All performance assessments were completed in the exercise lab and supervised by trained research assistants.

Anaerobic capacity After completion of muscular strength and endurance protocols and $5 \mathrm{~min}$ of rest, anaerobic capacity was assessed using the Wingate anaerobic capacity test on a Monark cycle ergometer (Ergomedic 894E, Vansboro, Sweden). The testing protocol began with a two-minute warm-up consisting of light pedaling $(<50$ $\mathrm{rpm})$ against zero resistance. The resistance for all Wingate testing was set at $7.5 \%$ of Week 0 body weight $(\mathrm{kg})$ for each participant and was not changed for any subsequent test. Seat height and position was assessed during the initial test and was standardized for each subsequent use. After the warm-up, participants were provided a three-second count down and instructed to increase pedal speed and reach maximal speed. Trained investigators manually dropped the resistance when the participant reached their maximal speed, and the participant continued to pedal as fast as possible against their allotted resistance for the 30-s test. Upon completion of the test, the resistance was removed, and participants transitioned into a two-minute cool down on the bike against zero resistance. Peak power, average power and time to fatigue was computed and used as indicators of anaerobic power and fatigue resistance.

\section{Resistance training program}

A template of the resistance-training program is outlined in Table 1. Participants were provided with online training cards via email following completion of the Week 0 performance assessment. Participants updated their training $\log$ online each week to provide accountability for each workout. The program was designed as a linear, split-body periodization program with two upper-body and two lower-body workouts each week [20]. A progressive overload scheme was followed to facilitate increases in strength and muscle mass. For the first 6 weeks (weeks 1-6), each workout consisted of three sets of ten repetitions at a $10 \mathrm{RM}$ load. On the final set of each exercise, participants performed as many repetitions as they were able. Following the autoregulatory model introduced by Mann et al. [21], if participants were able to complete 12 or more repetitions on their final set, they were instructed to increase the load for their next workout. During the final 4 weeks (weeks $7-$ 10), each workout consisted of four sets of six repetitions to momentary muscle failure. Again, participants completed as many repetitions as they were able on their final set. If participants completed seven or more repetitions on their final set, they were assigned to the next highest load for their next workout [21]. One minute of rest in between sets was allotted for weeks 1-6, while 2 min of rest between each set were followed for weeks 710. Each resistance training session took approximately $60 \mathrm{~min}$ to complete. Completion of the program was not directly supervised. To maximize ecological validity, participants completed their workouts in the facility of their choosing, provided they had access to all equipment necessary to complete the exercises within the program. All study participants completed the first 2 weeks of the strength training protocol without supplementation for two primary reasons. First, to allow participants to identify what loads were needed to reach momentary muscular failure for each exercise on their third prescribed set. Second, this two-week period allowed for neuromuscular acclimation to the training stimulus, which may have 
Table 1 Sample resistance training program

\begin{tabular}{|c|c|c|}
\hline Weeks & Day 1, Day 3 & Day 2, Day 4 \\
\hline $1-6^{a}$ & $\begin{array}{l}\text { Bench press, } 3 \times 10 \mathrm{RM} \\
\text { Chest flies, } 3 \times 10 \mathrm{RM} \\
\text { Lat pull, } 3 \times 10 \mathrm{RM} \\
\text { Seated row, } 3 \times 10 \mathrm{RM} \\
\text { Shoulder press, } 3 \times 10 \mathrm{RM} \\
\text { Shoulder shrugs, } 3 \times 10 \mathrm{RM} \\
\text { Biceps curls, } 3 \times 10 \mathrm{RM} \\
\text { Triceps extensions, } 3 \times 10 \mathrm{RM}\end{array}$ & $\begin{array}{l}\text { Back squat or leg press, } 3 \times 10 \mathrm{RM} \\
\text { Leg extensions, } 3 \times 10 \mathrm{RM} \\
\text { Romanian Deadlift, } 3 \times 10 \mathrm{RM} \\
\text { Split Lunges, } 3 \times 10 \mathrm{RM} \\
\text { Leg curls, } 3 \times 10 \mathrm{RM} \\
\text { Calf raises, } 3 \times 10 \mathrm{RM} \\
\text { Ab crunches, } 3 \times 25\end{array}$ \\
\hline $7-10^{b}$ & $\begin{array}{l}\text { Bench press, } 4 \times 6 \mathrm{RM} \\
\text { Chest flies, } 4 \times 6 \mathrm{RM} \\
\text { Lat pull, } 4 \times 6 \mathrm{RM} \\
\text { Seated row, } 4 \times 6 \mathrm{RM} \\
\text { Shoulder press, } 4 \times 6 \mathrm{RM} \\
\text { Shoulder shrugs, } 4 \times 6 \mathrm{RM} \\
\text { Biceps curls, } 4 \times 6 \mathrm{RM} \\
\text { Triceps extensions, } 4 \times 6 \mathrm{RM}\end{array}$ & $\begin{array}{l}\text { Back squat or leg press, } 4 \times 6 \text { RM } \\
\text { Leg extensions, } 4 \times 6 \text { RM } \\
\text { Deadlift, } 4 \times 6 \text { RM } \\
\text { Lunges, } 4 \times 6 \mathrm{RM} \\
\text { Leg curls, } 4 \times 6 \mathrm{RM} \\
\text { Calf raises, } 4 \times 6 \mathrm{RM} \\
\text { Ab crunches, } 3 \times 25\end{array}$ \\
\hline
\end{tabular}

${ }^{a}$ One-minute rest between sets

${ }^{\mathrm{b}} \mathrm{Tw}$ o minutes rest between sets

occurred due to prescribing participants to follow a training program different than what they had been following.

To monitor compliance to the resistance-training program, participants were instructed to complete the online training cards (Google Sheets) weekly by selecting the exercise completed and filling out the number of reps and load used. Completion of logs was monitored weekly by research team members and emails were sent or phone calls made to facilitate compliance. In addition, participants were required to submit daily photographs of them in their gym either before or after their workouts. On each training day, participants would take a photograph of themselves at the gym and submit it through text, email, or an Instagram direct message. All training cards were reviewed, and photos were logged by laboratory staff weekly to monitor compliance to the training protocol. Compliance was calculated as the percentage of completed workouts. Participants were required to achieve and maintain at least $90 \%$ workout completion throughout the study. Compliance to recording their workout information and submitting pictures was determined to be $99.8 \%$ for the whey protein group and $99.4 \%$ for the rice protein group.

\section{Dietary protocol}

After the Week 0 performance assessment, participants were provided daily dietary recommendations. A range of daily caloric needs was estimated for each study participant by calculating resting energy expenditure using an average of the Harris-Benedict [22] and Mifflin-St. Joer [23] formulas and then multiplying that value by an activity factor of 1.6 and 1.8. Participants were also instructed to maintain a daily protein intake of 1.6 to $1.8 \mathrm{~g}$ of protein per kilogram of body mass [3]. Participants were required to $\log$ their dietary intake at least 4 days each week through MyFitnessPal over the course of the study. Dietary intake data can be found in Table 2 .

To achieve compliance to the dietary recommendations outlined above, study participants used MyFitnessPal (Under Armour, Baltimore, MD) to set up profiles and track their dietary intake. In addition, study participants were provided a binder that outlined their recommended energy and protein intakes throughout the study protocol. Participants were given examples of how to successfully fill out their food information in addition to graphic-based examples of portion size estimators. Laboratory staff reviewed the food records weekly and documented if the participants met both caloric and protein requirements 4 days per week. Finally, when participants visited the laboratory every 2 weeks to receive more supplements, their records were reviewed, and questions were asked regarding compliance to the diet, exercise, and supplementation.

\section{Supplementation protocol}

Following performance re-assessment 2 weeks after beginning the resistance-training program, participants were randomly assigned to the whey protein or rice protein groups in a double-blind fashion. Participants were then block randomized within each protein group based on their week two fat-free mass using an online randomization software program (Random Allocation Software). Participants were provided with 15 doses of $24 \mathrm{~g}$ of rice protein $(33.6 \mathrm{~g}$ of chocolate flavored rice protein concentrate, Growing Naturals, LLC, Axiom Foods) or $24 \mathrm{~g}$ of whey protein (32.6 g of chocolate flavored whey protein concentrate, NutraBio Labs, Inc.). Each 24$\mathrm{g}$ dose of protein was mixed with 6-12 fluid ounces of cold water. On workout days, participants ingested one dose within $60 \mathrm{~min}$ of completing their workout. On non-workout days, one dose was ingested within $60 \mathrm{~min}$ 
Table 2 Dietary Variables

\begin{tabular}{|c|c|c|c|c|c|c|c|c|}
\hline Variable & Group & Week 2 & Week 4 & Week 6 & Week 8 & Week 10 & $\begin{array}{l}\text { Within Group } \\
(p)\end{array}$ & $\mathrm{G} \times \mathrm{T}(p)$ \\
\hline \multirow[t]{2}{*}{ Caloric Intake (kcal/day) } & Rice & $2583 \pm 930$ & $2678 \pm 941$ & $2895 \pm 436$ & $2609 \pm 921$ & $2361 \pm 1178$ & 0.57 & 0.34 \\
\hline & Whey & $3168 \pm 336$ & $2786 \pm 921$ & $2483 \pm 1211$ & $2655 \pm 891$ & $2672 \pm 919$ & 0.34 & \\
\hline \multirow{2}{*}{$\begin{array}{l}\text { Relative Caloric Intake } \\
\text { (kcal/kg) }\end{array}$} & Rice & $29.1 \pm 10.3$ & - & - & - & $26.2 \pm 12.7$ & 0.57 & 0.61 \\
\hline & Whey & $36.7 \pm 4.9$ & - & - & - & $30.7 \pm 10.6$ & 0.08 & \\
\hline \multirow{2}{*}{$\begin{array}{l}\text { Carbohydrate } \\
\text { (g/day) }\end{array}$} & Rice & $280 \pm 107$ & $302 \pm 119$ & $323 \pm 80$ & $294 \pm 125$ & $262 \pm 130$ & 0.61 & 0.36 \\
\hline & Whey & $332 \pm 98$ & $311 \pm 139$ & $267 \pm 158$ & $278 \pm 134$ & $287 \pm 139$ & 0.41 & \\
\hline \multirow{2}{*}{$\begin{array}{l}\text { Relative Carbohydrate } \\
\text { (g/kg/day) }\end{array}$} & Rice & $3.16 \pm 1.19$ & - & - & - & $2.91 \pm 1.43$ & 0.67 & 0.61 \\
\hline & Whey & $3.85 \pm 1.17$ & - & - & - & $3.27 \pm 1.48$ & 0.11 & \\
\hline \multirow[t]{2}{*}{ Protein (g/day) } & Rice & $157 \pm 62$ & $138 \pm 50$ & $157 \pm 29$ & $135.8 \pm 53$ & $130 \pm 67$ & 0.47 & 0.57 \\
\hline & Whey & $167 \pm 27$ & $153 \pm 57$ & $141 \pm 70$ & $147 \pm 50$ & $153 \pm 50$ & 0.63 & \\
\hline \multirow{2}{*}{$\begin{array}{l}\text { Relative Protein } \\
(\mathrm{g} / \mathrm{kg})\end{array}$} & Rice & $1.79 \pm 0.76$ & - & - & - & $1.43 \pm 0.70$ & 0.25 & 0.57 \\
\hline & Whey & $1.93 \pm 0.26$ & - & - & - & $1.76 \pm 0.60$ & 0.33 & \\
\hline \multirow{2}{*}{$\begin{array}{l}\text { Fat } \\
\text { (g/day) }\end{array}$} & Rice & $95 \pm 37$ & $101 \pm 40$ & $109 \pm 28$ & $97 \pm 47$ & $86 \pm 46$ & 0.60 & 0.16 \\
\hline & Whey & $129 \pm 32$ & $104 \pm 40$ & $93 \pm 49$ & $106 \pm 39$ & $104 \pm 36$ & 0.18 & \\
\hline \multirow{2}{*}{$\begin{array}{l}\text { Relative Fat } \\
(\mathrm{g} / \mathrm{kg})\end{array}$} & Rice & $1.07 \pm 0.40$ & - & - & - & $0.95 \pm 0.50$ & 0.58 & 0.47 \\
\hline & Whey & $1.50 \pm 0.38$ & - & - & - & $1.20 \pm 0.44$ & 0.07 & \\
\hline
\end{tabular}

All data presented as Mean \pm SD; $p=$ probability of making a type I error

All variables relative to body mass use body mass obtained during Week 2

Table 3 Amino Acid Composition

\begin{tabular}{|c|c|c|c|c|}
\hline & \multicolumn{2}{|l|}{ Whey Protein } & \multicolumn{2}{|l|}{ Rice Protein } \\
\hline & AA (mg/serving) & AA (mg/g protein) & AA (mg/serving) & AA (mg/g protein) \\
\hline Aspartic acid & 2512 & 104.2 & 2213 & 89.2 \\
\hline Threonine & 1625 & 67.4 & 909 & 36.7 \\
\hline Serine & 1193 & 49.5 & 1272 & 51.3 \\
\hline Glutamic Acid & 3966 & 164.6 & 4319 & 174.2 \\
\hline Proline & 1424 & 59.1 & 1181 & 47.6 \\
\hline Glycine & 423 & 17.6 & 1114 & 44.9 \\
\hline Alanine & 1210 & 50.2 & 1446 & 58.3 \\
\hline Valine & 1327 & 55.1 & 1466 & 59.1 \\
\hline Isoleucine & 1520 & 63.1 & 1114 & 44.9 \\
\hline Leucine & 2509 & 104.1 & 2118 & 85.4 \\
\hline Tyrosine & 771 & 32.0 & 1374 & 55.4 \\
\hline Phenylalanine & 717 & 29.8 & 1378 & 55.6 \\
\hline Lysine & 2247 & 93.2 & 705 & 28.4 \\
\hline Histidine & 411 & 17.1 & 553 & 22.3 \\
\hline Arginine & 673 & 28.0 & 2006 & 80.9 \\
\hline Cystine & 585 & 24.3 & 581 & 23.4 \\
\hline Methionine & 533 & 22.1 & 681 & 27.5 \\
\hline Tryptophan & 455 & 18.9 & 352 & 14.2 \\
\hline Essential AAs (mg) & 11,344 & 471 & 9276 & 374 \\
\hline Total BCAAs (mg) & 5356 & 222 & 4698 & 189 \\
\hline Total Amino Acids (g) & 24.1 & 1 & 24.8 & 1 \\
\hline
\end{tabular}


of going to bed. The total protein content and amino acid profile for both protein supplements were analyzed by an independent laboratory, (Eurofins Food Chemistry Testing US, Inc., Madison, WI, USA) and can be found in Table 3. Both protein groups were isocaloric and isonitrogenous. Additionally, samples of the rice protein and whey protein were third-party analyzed by LGC Sciences, Inc. (Lexington, KY, www.Igcgroup.com) for the presence of banned substances. Each supplement was analyzed for over 214 compounds of interest using a variety of techniques including GC-MS/MS, LC-MS/MS, and LC-HRMS. All tests were found to be negative for all compounds targeted within LGC's core supplement screen.

To monitor compliance to the supplementation regimen, participants were required to visit the laboratory every 2 weeks where they were given an additional 15 sachets of their assigned protein. This time was taken to review compliance to the dietary recommendations, completion of dietary records, training program, and adverse events. In addition, on training and non-training days, participants were required to submit a photograph of themselves with the supplement in a clear container prior to its consumption. All photos were submitted via text, email, or Instagram direct message, in an identical fashion to the evidentiary photographs for the resistance training program. Supplement photos were logged by laboratory staff to ensure that participants were regularly consuming their protein doses. For the next three visits (Weeks 4, 6, 8), participants were required to return to the lab to exchange their empty sachets for 15 new doses. To achieve compliance, participants were required to submit a returned sachet and submit a photograph. Compliance was calculated as the percentage of days in which compliance was achieved divided by the total number of days in the protocol. Compliance to the supplementation protocol was calculated to be $99.4 \%$ for the whey protein group and $99.6 \%$ for the rice protein group.

\section{Statistical analysis}

All analyses were completed using Microsoft Excel and the Statistical Package for the Social Sciences (v23; SPSS Inc., Chicago IL). A priori statistical analysis using GPower revealed that achieving an effect size of 0.25 with an alpha level of 0.05 and power of 0.80 would require a total sample size of 22 participants. Before any statistical tests are performed, data was analyzed for normality. All non-normal data were log-transformed prior to analysis. For all statistical tests, data were considered statistically significant when the probability of a type I error was 0.05 or less. Primary endpoints for this investigation were fatfree mass and leg press 1RM. Secondary endpoints were fat mass, lean mass, and \% body fat along with bench press $1 \mathrm{RM}$, bench press repetitions to fatigue, leg press repetitions to fatigue, leg press volume, peak anaerobic power, mean anaerobic power, and rate of fatigue. $2 \times 2$ mixed factorial (group $\mathrm{x}$ time) ANOVAs with repeated measures on time were used to determine any statistically significant differences for time and group main effects and group $\mathrm{x}$ time interaction effects for all primary and secondary outcomes. $2 \times 5$ repeated measures ANOVA were used for all group $\mathrm{x}$ time, time, and group effects for all dietary variables. In instances, where baseline group differences were evident, ANCOVA analysis was completed with the respective baseline value as a covariate. All data are presented as means \pm standard deviations.

\section{Results}

\section{Baseline differences}

In response to recruitment flyers, study team members made contact with 313 individuals. A large majority $(n=$ 244) were excluded, while 69 people were consented. Of the exclusions, 209 did not meet inclusion criteria while an additional 35 withdrew prior to randomization. The remaining 34 participants were randomized, with 16 being assigned to ingest whey protein and 18 being assigned to ingest rice protein. Four people in the whey group were lost to follow up due to failure to maintain contact or non-compliance, while six people in the rice group were lost to follow-up due to failure to maintain contact with research team member or non-compliance with the protocol. This led to two groups of 12 participants in each group that were included in the analysis (Fig. 2). Prior to starting the resistance training and supplementation protocols, independent $\mathrm{t}$-tests revealed no baseline differences $(p>0.05)$ between groups for age (95\% CI: $-3.8,7.6$ years, $p=0.50)$, height (95\% CI: $-7.7,7.1 \mathrm{~cm}, p=0.93)$, body mass (95\% CI: $-9.1,5.5 \mathrm{~kg}, p=0.61)$, body mass index ($\left.2.13,1.20 \mathrm{~kg} / \mathrm{m}^{2}, p=0.57\right)$, systolic blood pressure $(95 \%$ CI: $-10.0,1.8 \mathrm{mmHg}, p=0.16$ ), diastolic blood pressure (95\% CI: $-1.8,7.0 \mathrm{mmHg}, p=0.23$ ), resting heart rate (95\% CI: $-7.2,5.4$ beats $/ \mathrm{min}, p=0.77)$, \% body fat $(95 \%$ CI: $-4.81,1.78 \%$ fat, $p=0.35)$, leg press $1 \mathrm{RM}(95 \% \mathrm{CI}:-$ $57,34 \mathrm{~kg}, p=0.61)$, and bench press $1 \mathrm{RM}$ (95\% CI: -9.3 , $19.5 \mathrm{~kg}, p=0.47)$.

\section{Dietary intake}

Dietary data was collected at two-week intervals throughout the study protocol and was analyzed using both normalized (per week 2 body mass in $\mathrm{kg}$ ) and nonnormalized data. Since body mass was only collected at the beginning and end of supplementation, normalized data was analyzed using $2 \times 2$ mixed factorial ANOVA with repeated measures of time. All non-normalized data was subsequently analyzed using $2 \times 5$ mixed factorial ANOVA with repeated measures on time. As seen in Table 2, group $\mathrm{x}$ time interactions, time, and group effects for all non-normalized data for energy (group $\mathrm{x}$ 


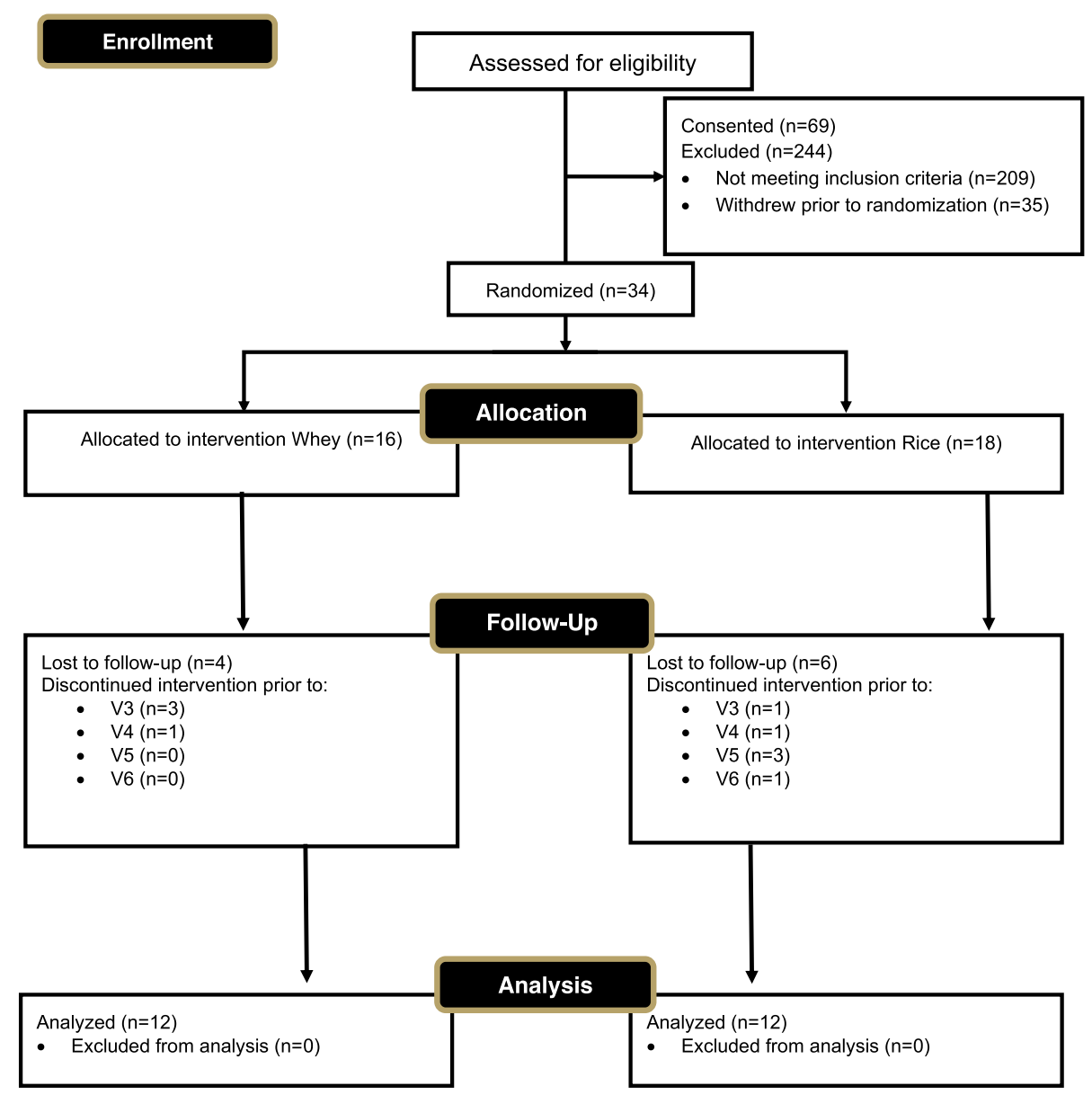

Fig. 2 CONSORT diagram

time: $p=0.34$; group: $p=0.54$; time: $p=0.67$ ), carbohydrate (group $\mathrm{x}$ time: $p=0.36$; group: $p=0.94$; time: $p=$ 0.73 ), protein (group x time: $p=0.57$; group: $p=0.51$; time: $p=0.52$ ), and fat (group $\mathrm{x}$ time: $p=0.16$; group: $p=0.36$; time: $p=0.55$ ) were non-significant. Additionally, similar outcomes were revealed when all data was represented relative to each person's recorded body mass: normalized energy (group $\mathrm{x}$ time: $p=0.61$; group: $p=0.94$; time: $p=0.15$ ), normalized carbohydrate (group $\mathrm{x}$ time: $p=0.61$; group: $p=0.24$; time: $p=0.21$ ), normalized protein (group $\mathrm{x}$ time: $p=0.57$; group: $p=0.21$; time: $p=0.14$ ), and normalized fat (group $\mathrm{x}$ time: $p=$ 0.47; group: $p=0.01$; time: $p=0.11$ ) (Table 2).

Baseline differences between groups were identified that revealed greater amounts of normalized energy (mean difference: $7.6 \pm 3.3 \mathrm{kcal} / \mathrm{kg}, 95 \%$ CI: $0.72,14.4 \mathrm{kcal} / \mathrm{kg}, p=0.03$ ) and normalized fat intake (mean difference: $0.43 \pm 0.16 \mathrm{~g} / \mathrm{kg}$, $95 \%$ CI: $0.10,0.76 \mathrm{~g} / \mathrm{kg}, p=0.01$ ) for the whey protein group when compared to the rice protein group. Follow-up ANCOVA were completed on this data with each respective baseline values as a covariate to assess changes in normalized energy and fat intakes between groups. ANCOVA results indicated no between-group differences for the normalized energy $(p=0.37)$ and fat intake $(p=0.28)$.

\section{Anthropometrics and body water}

Table 4 highlights main effects for group $\mathrm{x}$ time interaction, time, and group effects for body mass, total body water, and body composition variables. Changes in body mass indicated a non-significant group $\mathrm{x}$ time interaction $(p=0.42$; Mean Difference: $0.58 \pm 0.70 \mathrm{~kg}$; $95 \%$ CI: $-0.88,2.03 \mathrm{~kg}, d=-0.07$ ), a significant main effect for time $(p=0.02)$, and a non-significant group effect $(p=0.59)$. As anticipated, similar changes were identified for body mass index within and between groups (data not shown, see Table 4). Changes in total body water indicated a non-significant group $\mathrm{x}$ time interaction $(p=$ 0.51; Mean Difference: $-0.52 \pm 0.79$ l; 95\% CI: $-2.16,1.11$ $1, d=0.12)$, significant main effect for time $(p=0.01)$, and a non-significant group effect $(p=0.61)$ (See Table 4).

\section{Body composition}

Changes in DXA lean mass indicated a non-significant group $\mathrm{x}$ time interaction $(p=0.37$; Mean Difference: 
Table 4 Hemodynamic and Body Composition Variables

\begin{tabular}{|c|c|c|c|c|c|c|c|c|}
\hline Variable & Group & Week 2 & Week 10 & ES & $95 \% \mathrm{Cl}$ & $\begin{array}{l}\text { Group x Time } \\
\text { (p) }\end{array}$ & $\begin{array}{l}\text { Time } \\
(p)\end{array}$ & $\begin{array}{l}\text { Group } \\
(p)\end{array}$ \\
\hline Heart Rate (beats/min) & $\begin{array}{l}\text { Whey } \\
\text { Rice }\end{array}$ & $\begin{array}{l}63.7 \pm 8.1 \\
58.0 \pm 9.6\end{array}$ & $\begin{array}{l}63.8 \pm 9.0 \\
59.0 \pm 10.2\end{array}$ & 0.10 & $(-7.2,5.4)$ & 0.77 & 0.73 & 0.15 \\
\hline $\begin{array}{l}\text { Systolic BP } \\
(\mathrm{mm} \mathrm{Hg})\end{array}$ & $\begin{array}{l}\text { Whey } \\
\text { Rice }\end{array}$ & $\begin{array}{l}124.9 \pm 10.7 \\
125.4 \pm 5.9\end{array}$ & $\begin{array}{l}120.5 \pm 10.3 \\
125.1 \pm 6.3\end{array}$ & 0.48 & $(-10.0,1.8)$ & 0.16 & 0.11 & 0.44 \\
\hline $\begin{array}{l}\text { Diastolic BP } \\
(\mathrm{mm} \mathrm{Hg})\end{array}$ & $\begin{array}{l}\text { Whey } \\
\text { Rice }\end{array}$ & $\begin{array}{l}69.1 \pm 8.6 \\
68.1 \pm 8.7\end{array}$ & $\begin{array}{l}69.8 \pm 9.0 \\
66.2 \pm 8.8\end{array}$ & 0.29 & $(-1.8,7.0)$ & 0.23 & 0.56 & 0.51 \\
\hline $\begin{array}{l}\text { Body Mass } \\
(\mathrm{kg})\end{array}$ & $\begin{array}{l}\text { Whey } \\
\text { Rice }\end{array}$ & $\begin{array}{l}87.0 \pm 8.7 \\
89.2 \pm 8.1\end{array}$ & $\begin{array}{l}88.2 \pm 9.1 \dagger \\
89.7 \pm 7.8\end{array}$ & -0.07 & $(-0.88,2.03)$ & 0.42 & 0.02 & 0.59 \\
\hline Body Mass Index $\left(\mathrm{kg} / \mathrm{m}^{2}\right)$ & $\begin{array}{l}\text { Whey } \\
\text { Rice }\end{array}$ & $\begin{array}{l}27.2 \pm 1.9 \\
27.8 \pm 1.9\end{array}$ & $\begin{array}{l}27.5 \pm 1.9 \dagger \\
27.9 \pm 1.8\end{array}$ & -0.08 & $(-0.34,0.65)$ & 0.51 & 0.07 & 0.51 \\
\hline Total Body Water (L) & $\begin{array}{l}\text { Whey } \\
\text { Rice }\end{array}$ & $\begin{array}{l}49.7 \pm 4.5 \\
50.4 \pm 4.2\end{array}$ & $\begin{array}{l}50.5 \pm 4.1 \dagger \\
51.7 \pm 4.4 \dagger\end{array}$ & 0.12 & $(-2.16,1.11)$ & 0.51 & 0.01 & 0.61 \\
\hline DXA Bone Content (kg) & $\begin{array}{l}\text { Whey } \\
\text { Rice }\end{array}$ & $\begin{array}{l}3.05 \pm 0.40 \\
3.13 \pm 0.30\end{array}$ & $\begin{array}{l}3.08 \pm 0.38 \\
3.10 \pm 0.28\end{array}$ & 0.20 & $(0.01,0.12)$ & 0.02 & 0.91 & 0.70 \\
\hline DXA Lean Mass (kg) & $\begin{array}{l}\text { Whey } \\
\text { Rice }\end{array}$ & $\begin{array}{l}63.4 \pm 5.3 \\
64.7 \pm 6.3\end{array}$ & $\begin{array}{l}64.5 \pm 5.7 \dagger \\
65.3 \pm 6.2 \dagger\end{array}$ & -0.10 & $(-0.73,1.91)$ & 0.37 & 0.01 & 0.60 \\
\hline DXA Fat Mass (kg) & $\begin{array}{l}\text { Whey } \\
\text { Rice }\end{array}$ & $\begin{array}{l}17.3 \pm 4.9 \\
18.4 \pm 3.7\end{array}$ & $\begin{array}{l}17.5 \pm 4.7 \\
18.4 \pm 3.4\end{array}$ & -0.06 & $(-0.48,1.02)$ & 0.46 & 0.60 & 0.54 \\
\hline DXA Fat-Free Mass (kg) & $\begin{array}{l}\text { Whey } \\
\text { Rice }\end{array}$ & $\begin{array}{l}65.9 \pm 5.6 \\
67.2 \pm 6.6\end{array}$ & $\begin{array}{l}67.0 \pm 5.8 \dagger \\
67.8 \pm 6.5 \dagger\end{array}$ & -0.11 & $(-0.68,1.99)$ & 0.32 & 0.01 & 0.60 \\
\hline DXA Body Fat (\%) & $\begin{array}{l}\text { Whey } \\
\text { Rice }\end{array}$ & $\begin{array}{l}20.6 \pm 4.2 \\
21.5 \pm 3.8\end{array}$ & $\begin{array}{l}20.5 \pm 3.9 \\
21.4 \pm 3.8\end{array}$ & 0.01 & $(-0.63,0.71)$ & 0.90 & 0.49 & 0.58 \\
\hline $\begin{array}{l}\text { Dry Lean Mass } \\
(\mathrm{kg})\end{array}$ & $\begin{array}{l}\text { Whey } \\
\text { Rice }\end{array}$ & $\begin{array}{l}16.7 \pm 2.1 \\
17.6 \pm 3.9\end{array}$ & $\begin{array}{l}17.1 \pm 2.5 \\
16.9 \pm 3.7\end{array}$ & -0.35 & $(-0.46,2.69)$ & 0.16 & 0.72 & 0.78 \\
\hline
\end{tabular}

$\dagger=$ Significant change $(p<0.05)$ within each group from each group's respective baseline; Time Main effect for time; $p$ probability level of making Type I error; 95\% Cl 95\% confidence intervals were computed on the observed changes from baseline between groups; ES Effect size calculated as ([Week 10 Rice Protein Week 2 Rice Protein] - [Week 10 Whey Protein - Week 2 Whey Protein]) / Pooled SD. DXA Dual-energy x-ray absorptiometry

$0.59 \pm 0.64 \mathrm{~kg} ; 95 \% \mathrm{CI}:-0.73,1.91 \mathrm{~kg}, d=-0.10)$, a significant main effect for time $(p=0.01)$, and nonsignificant group effect $(p=0.60)$. Changes in dry lean mass (DXA lean mass - total body water) indicated a non-significant group $\mathrm{x}$ time interaction $(p=0.16$, Mean Difference; $1.11 \pm 0.76,95 \% \mathrm{CI}:-0.46,2.69 \mathrm{~kg}, \mathrm{~d}=-$ $0.35)$, time $(p=0.72)$, and group effect $(p=0.16)$. Changes in DXA fat mass indicated no group $\mathrm{x}$ time interaction $(p=0.46$; Mean Difference: $0.27 \pm 0.36 \mathrm{~kg}$; 95\% CI: $-0.48,1.02 \mathrm{~kg}, d=-0.06)$, time $(p=0.60)$, or group effects $(p=0.54)$ for fat mass. Fat-free mass (Fig. 3a and $\mathrm{b}$ ) changes identified no significant group $\mathrm{x}$ time interaction ( $p=0.32$; Mean Difference: $0.66 \pm 0.64$ $\mathrm{kg} ; 95 \% \mathrm{CI}:-0.68,1.99 \mathrm{~kg}, d=-0.11$ ) and time effect $(p=0.01)$ and no significant main effect for group ( $p=$ 0.60 ) was realized (Table 4 ). Changes in DXA percent fat changes indicated no group $\mathrm{x}$ time interaction $(p=$ 0.90; Mean Difference: $0.04 \pm 0.32 \%$ fat; $95 \% \mathrm{CI}$ : -0.63 , $0.71 \%$ fat, $d=0.01)$, time $(p=0.49)$, or group $(p=0.58)$ effect. Bone mineral content changes did yield a significant group $\mathrm{x}$ time interaction $(p=0.02$; Mean Difference: $0.07 \pm 0.03 \mathrm{~kg} ; \quad 95 \% \mathrm{CI}: 0.01,0.12 \mathrm{~kg}, d=0.20$ ) while no significant main effect for time $(p=0.91)$ or group $(p=0.70)$ was found.

\section{Exercise performance Muscular strength}

As seen in Table 5, changes in leg press 1RM indicated a non-significant group $\mathrm{x}$ time interaction $(p=0.80$; Mean Difference: $5.42 \pm 21.3 \mathrm{~kg}$; $95 \% \mathrm{CI}:-38.7,49.6 \mathrm{~kg}, d=$ $0.05)$, significant main effect for time $(p<0.001)$, and a non-significant group effect $(p=0.50)$. Within-group changes indicated both the rice and whey protein groups experienced significant improvements in their leg press $1 \mathrm{RM}$ at week $10(p<0.001)$. Changes in bench press $1 \mathrm{RM}$ (Fig. 4a and b) indicated a non-significant group $\mathrm{x}$ time interaction $(p=0.51$; Mean Difference: $-3.33 \pm$ $5.03 \mathrm{~kg} ; 95 \%$ CI: $-13.8,7.09 \mathrm{~kg}, d=0.09$ ), significant main effect for time $(p<0.001)$, and non-significant main effect for group $(p=0.68)$.

\section{Muscular endurance}

Changes in leg press repetitions to fatigue indicated a non-significant group $\mathrm{x}$ time interaction $(p=0.50$; Mean Difference: $0.83 \pm 1.21$ reps; $95 \% \mathrm{CI}:-1.68,3.35$ reps, $d=-0.24)$, significant main effect for time $(p=0.03)$, and non-significant main effect for group $(p=0.12)$. Changes in bench press repetitions to fatigue indicated a non-significant group $\mathrm{x}$ time interaction $(p=0.16$; Mean 

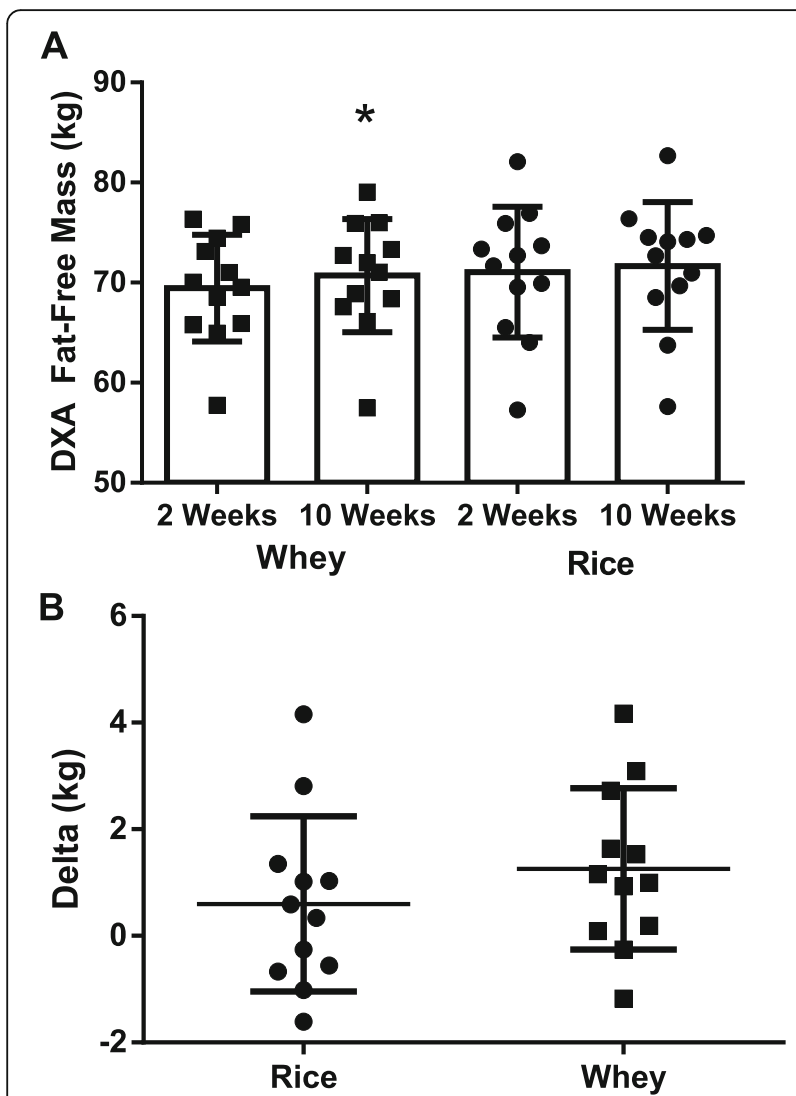

Fig. 3 (Sub-Panel $\mathbf{a}$ \& $\mathbf{b}$ ): DXA fat-free mass (in kilograms) in rice and whey protein supplemented groups. Panel a: Raw data (Rice $=$ $0.05 \pm 4.8 \%$ change; Whey $=1.5 \pm 4.5 \%$ change); Panel b: Individual response data. All data is presented as means \pm SD. ${ }^{*}=$ Different from within-group week 0 value

Difference: $-0.83 \pm 0.57$ reps; $95 \%$ CI: $-2.02,0.35$ reps, $d=-0.46)$, non-significant main effect for time $(p=$ $0.57)$, a non-significant main effect for group $(p=0.91)$. Bench press volume (80\% 1RM x reps performed) was calculated at each study visit as a measure of muscular endurance. No group $\mathrm{x}$ time interaction $(p=0.13)$, time $(p=0.16)$, or group effects $(p=0.56)$ were identified. Leg press volume was computed in a similar fashion (1RM x reps performed) and no main effect for time $(p=0.38)$, group $(p=0.20)$, or group $\mathrm{x}$ time interaction was observed. $(p=0.51)$. In addition, total resistance training volume (sets $\mathrm{x}$ reps $\mathrm{x}$ load) was calculated for the entire eight-week protocol. No significant differences between group were found for upper-body (Whey: 195,806 \pm 34 , $992 \mathrm{~kg}$ vs. Rice: $191,327 \pm 41,215 \mathrm{~kg}, p=0.78$ ), lowerbody (Whey: 229,736 $\pm 72,732 \mathrm{~kg}$ vs. Rice: $240,564 \pm 54$, $455 \mathrm{~kg}, p=0.69$ ), and total volume (Whey: $425,542 \pm$ $104,564 \mathrm{~kg}$ vs. Rice: $431,891 \pm 91,615 \mathrm{~kg}, p=0.88)$.

\section{Anaerobic capacity}

Peak power, mean power, and rate of fatigue were assessed in response to completion of the Wingate anaerobic capacity test. All power data was normalized to each person's body mass in $\mathrm{kg}$ before being analyzed statistically. Changes in normalized peak power (watts/ $\mathrm{kg}$ ) indicated a non-significant group $\mathrm{x}$ time interaction $(p=0.76$; Mean Difference: $-9.6 \pm 30.4$ watts $/ \mathrm{kg}$; $95 \%$ CI: $-72.5,53.4$ watts $/ \mathrm{kg})$, time $(p=0.54)$, or group $(p=$ 0.53 ) effect. Changes in normalized mean power (watts/ $\mathrm{kg}$ ) indicated a non-significant group $\mathrm{x}$ time interaction $(p=0.94$; Mean Difference: $-0.01 \pm 0.16$ watts $/ \mathrm{kg}$; $95 \%$ CI: $-0.34,0.32$ watts $/ \mathrm{kg})$, time $(p=0.12)$, and group $(p=0.77)$ effects. Changes in Wingate power drop (maximum power - minimum power) indicated a nonsignificant group $\mathrm{x}$ time interaction $(p=0.97$; Mean Difference: $1.62 \pm 48.0$ watts; $95 \%$ CI: $-98.0,101.3$ watt), time $(p=0.96)$, or group $(p=0.44)$ effect.

\section{Discussion}

We sought to examine if daily supplementation with $24-\mathrm{g}$ doses of rice or whey protein concentrate during an eightweek resistance training program differentially impacts changes in strength and body composition in resistancetrained men. Primary outcomes of interest included changes in upper- and lower-body strength and DXAdetermined fat-free mass, while secondary outcomes included changes in muscular endurance, resistance training volume, anaerobic power, fat mass, percent fat, bone mass, and body water. Findings relating to the primary outcomes indicated statistically significant improvements in body mass, total body water, lean mass, fat-free mass (Fig. 3), bench press 1RM (Fig. 4), and leg press 1RM over time with no differences between protein source. Moreover, no differences between protein sources were identified for all primary and secondary variables.

Previous research has established that rates of MPS and muscle protein breakdown increase in response to an acute bout of resistance training [4, 24]. Further, acute resistance training responses indicate that breakdown rates increase to a larger magnitude, resulting in a net negative muscle protein balance [24]. The provision of amino acids in the form of free amino acids or dietary proteins in dosages that provide $8-12 \mathrm{~g}$ of the essential amino acids promote maximal rates of MPS [25], ultimately resulting in a net positive muscle protein balance [25]. The quality of provided proteins can differ depending on the status of several factors, such as the amount of amino acids provided (especially the essential amino acids), the proportion at which those amino acids are delivered, and digestibility of the protein [5]. In general, plant-derived protein sources are considered to be of a lower quality as they typically are comprised of lower amounts of total essential amino acids, are low in one or more of the essential amino acids, and have lower levels of protein digestibility [9]. 
Table 5 Performance Variables

\begin{tabular}{|c|c|c|c|c|c|c|c|c|}
\hline Variable & Group & Week 2 & Week 10 & ES & $(95 \% \mathrm{Cl})$ & $\begin{array}{l}\text { Group x Time } \\
\text { (p) }\end{array}$ & Time $(p)$ & Group $(p)$ \\
\hline Bench Press 1RM (kg) & $\begin{array}{l}\text { Whey } \\
\text { Rice }\end{array}$ & $\begin{array}{l}114.4 \pm 13.2 \\
110.8 \pm 19.2\end{array}$ & $\begin{array}{l}117.0 \pm 14.1 \\
114.9 \pm 19.5 \dagger\end{array}$ & 0.09 & $(-13.8,7.1)$ & 0.51 & 0.01 & 0.68 \\
\hline Bench Press Reps to Fatigue & $\begin{array}{l}\text { Whey } \\
\text { Rice }\end{array}$ & $\begin{array}{l}7.3 \pm 1.4 \\
6.8 \pm 2.3\end{array}$ & $\begin{array}{l}7.1 \pm 1.7 \\
7.4 \pm 1.8\end{array}$ & -0.46 & $(-2.02,0.35)$ & 0.16 & 0.57 & 0.91 \\
\hline Bench Press Volume & $\begin{array}{l}\text { Whey } \\
\text { Rice }\end{array}$ & $\begin{array}{l}1829 \pm 307 \\
1617 \pm 487\end{array}$ & $\begin{array}{l}1818 \pm 449 \\
1847 \pm 444 \dagger\end{array}$ & 0.56 & $(-556,76)$ & 0.13 & 0.16 & 0.56 \\
\hline $\begin{array}{l}\text { Leg Press 1RM } \\
(\mathrm{kg})\end{array}$ & $\begin{array}{l}\text { Whey } \\
\text { Rice }\end{array}$ & $\begin{array}{l}315 \pm 42 \\
331 \pm 60\end{array}$ & $\begin{array}{l}342 \pm 41 \dagger \\
355 \pm 62 \dagger\end{array}$ & 0.05 & $(-38.8,49.6)$ & 0.80 & $<0.001$ & 0.50 \\
\hline Leg Press Reps to Fatigue & $\begin{array}{l}\text { Whey } \\
\text { Rice }\end{array}$ & $\begin{array}{l}12.3 \pm 3.1 \\
10.6 \pm 3.5\end{array}$ & $\begin{array}{l}11.3 \pm 4.4 \\
8.8 \pm 2.7\end{array}$ & -0.24 & $(-1.68,3.35)$ & 0.50 & 0.03 & 0.12 \\
\hline Leg Press Volume & $\begin{array}{l}\text { Whey } \\
\text { Rice }\end{array}$ & $\begin{array}{l}8538 \pm 2487 \\
7542 \pm 2323\end{array}$ & $\begin{array}{l}8438 \pm 3276 \\
6822 \pm 2591\end{array}$ & -0.23 & $(-1289,2530)$ & 0.51 & 0.38 & 0.20 \\
\hline Wingate Peak Power (W/kg) & $\begin{array}{l}\text { Whey } \\
\text { Rice }\end{array}$ & $\begin{array}{l}9.5 \pm 1.0 \\
9.7 \pm 1.2\end{array}$ & $\begin{array}{l}9.3 \pm 1.0 \\
9.7 \pm 1.3\end{array}$ & 0.16 & $(-0.91,0.54)$ & 0.60 & 0.54 & 0.53 \\
\hline Wingate Mean Power (W/kg) & $\begin{array}{l}\text { Whey } \\
\text { Rice }\end{array}$ & $\begin{array}{l}7.4 \pm 0.7 \\
7.5 \pm 1.0\end{array}$ & $\begin{array}{l}7.2 \pm 0.7 \\
7.3 \pm 0.9\end{array}$ & -0.02 & $(-0.34,0.32)$ & 0.94 & 0.12 & 0.77 \\
\hline Wingate Power Drop (watts) & $\begin{array}{l}\text { Whey } \\
\text { Rice }\end{array}$ & $\begin{array}{l}403 \pm 102 \\
433 \pm 111\end{array}$ & $\begin{array}{l}405 \pm 107 \\
433 \pm 104\end{array}$ & -0.02 & $(-98,101)$ & 0.97 & 0.96 & 0.44 \\
\hline
\end{tabular}

$\dagger=$ Significant change $(p<0.05)$ within each group from each group's respective baseline; Time Main effect for time; $p$ probability level of making Type I error; $95 \% \mathrm{Cl}=95 \%$ confidence intervals were computed on the observed changes from baseline between groups; ES =Effect size calculated as ([Week 10 Rice Protein Week 2 Rice Protein] - [Week 10 Whey Protein - Week 2 Whey Protein]) / Pooled SD. Wingate power drop = Wingate maximum power - Wingate minimum power

In accordance with the findings of Joy et al. [12], results from the present study identified significant improvements in body mass $(p=0.42$; Mean Difference: $0.58 \pm 0.70 \mathrm{~kg} ; 95 \% \mathrm{CI}:-0.88,2.03 \mathrm{~kg}, d=-0.07)$ and fat-free mass $(p=0.32$; Mean Difference: $0.66 \pm 0.64 \mathrm{~kg}$; $95 \%$ CI: $-0.68,1.99 \mathrm{~kg}, d=-0.11$, Fig. 3) with no differences between protein sources. No significant group $\mathrm{x}$ time interactions were observed for any of the performance outcomes that were measured (Fig. 4, Table 5). Furthermore, findings from the present study align with the work of Babault et al. [26] who randomized 161 males between the ages of $18-35$ years in a double-blind fashion to consume two daily 25 -g doses ( $50 \mathrm{~g}$ total) of pea protein, whey protein, or placebo in conjunction a 12-week resistance-training program. The authors concluded that protein supplementation increased muscle thickness more than placebo, with these differences reaching statistical significance in the weakest individuals, but no differences being present between the protein groups. While our findings align with some of the recent work involving plant proteins and their ability to stimulate resistance training adaptations, our results contradict earlier scientific reports suggesting plantbased proteins, mainly soy protein, may not be suitable sources to potentiate resistance-training induced improvements in strength and body composition, and the majority [27-29], but not all [30,31], of that work suggests whey protein is superior to soy protein. We also reported that whey protein was responsible for significantly greater increases in bone mineral content as measured by DXA (Table 4). A recent review by Deane et al. [32] highlighted several studies that demonstrate an increase in protein intake is commonly associated with improvements in bone status, but more research is needed regarding the impact of various protein sources before more definitive conclusions can be reached. Additionally, the length of our investigation would be considered by many to be too short to appropriately assess changes in bone status, so readers are encouraged to consider these factors prior to drawing firm conclusions surrounding the ability or inability of our two protein sources to impact bone status.

The primary basis for the reported inferiority of plantbased proteins focuses is their lower essential amino acid content and reduced digestibility. While the latter was not evaluated in the present study, a third-party independent analysis of each test protein revealed that when compared to rice protein, whey protein delivered approximately $26 \%$ more essential amino acids (471 vs. $374 \mathrm{mg}$ of essential amino acids per gram of protein) and $22 \%$ more leucine $(104.1$ vs. $85.4 \mathrm{mg}$ of leucine per gram of protein) (Table 3). Leucine is well accepted for its ability to stimulate the translation of cellular (including myofibrillar) proteins [33, 34], but the saturating dosage continues to be refined in humans. Using an animal model, Norton and colleagues [11,35] suggested that a $2-3 \mathrm{~g}$ dose may be needed to stimulate protein translation, while previous work in healthy humans by Moore and colleagues [36] indicated a plateau of MPS rates beyond a $20-\mathrm{g}$ dose of egg protein (which contains 


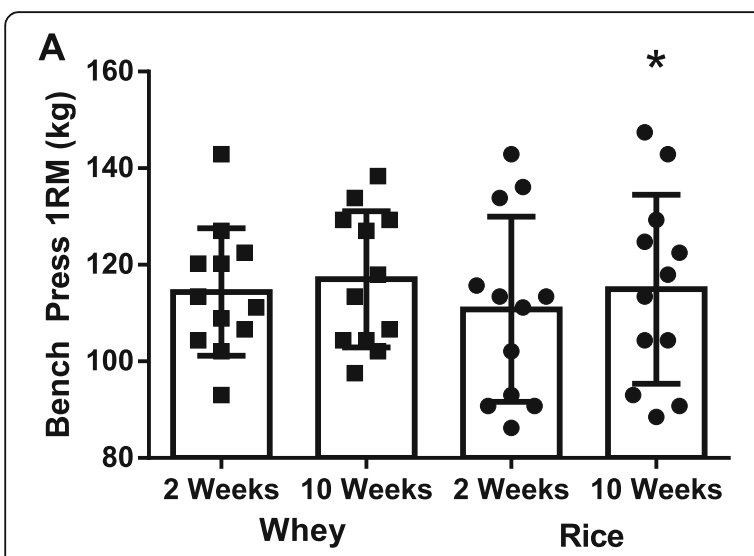

B

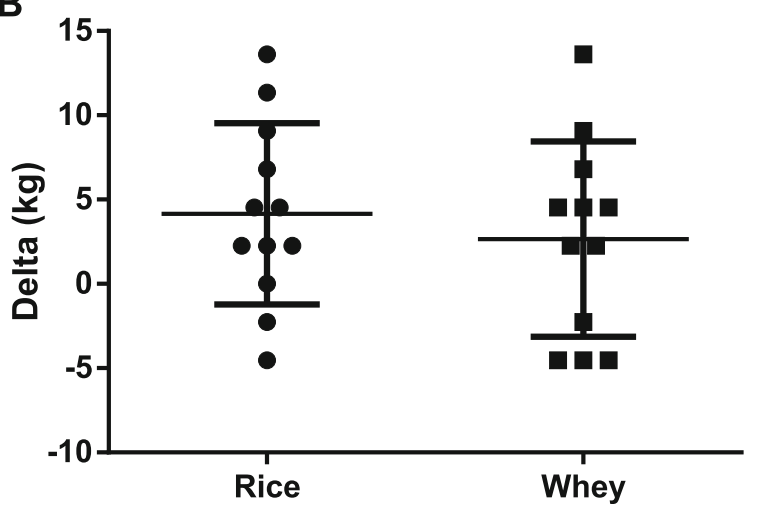

Fig. 4 (Sub-Panel $\mathbf{a}$ \& b): Bench-press one-repetition maximum (1RM) in rice and whey protein supplemented groups. Panel a: Raw data (Rice $=3.9 \pm 4.9 \%$ change; Whey $=2.4 \pm 5.0 \%$ change); Panel b: Individual response data. All data is presented as means \pm SD. ${ }^{*}=$ Different from within-group week 0 value

approximately two grams of leucine). Additionally, Churchward-Venne et al. [10] examined the acute and prolonged changes in MPS rates after ingesting a 25-g dose of whey protein or a $6.25-\mathrm{g}$ dose of whey with added leucine (to make the provided leucine equivalent to a 25-g dose). These authors concluded that a lower dose of whey protein with added leucine similarly stimulated MPS, but that the 25-g dose was best suited to increase muscle protein accretion. In this respect, other sources of protein that have lower amounts of leucine and other amino acids may not be able to stimulate acute increases in MPS to the same degree, but might be equal when it comes to stimulating accretion of skeletal muscle protein. In the present study, a dose of $2.1 \mathrm{~g}$ of leucine was provided, while the leucine content delivered in the Babault study [26] is approximated (based on amino acid content data presented in their paper) to have delivered $1.6 \mathrm{~g}$ during each of the two daily doses provided in the study. While more research is needed, the combination of findings from these studies seem to indicate that supplemental doses of plant proteins (rice and pea specifically) can similarly promote resistance training adaptations when compared to supplemental doses of whey protein of identical energy and protein content. Researchers have posited that the leucine dose needed to maximally stimulate MPS may progressively lower with chronic resistance training and protein supplementation, provided adequate daily protein intake is consumed (1.6-1.75 g/kg body mass). Previously, Phillips and colleagues [37] reported on the changes that occur in protein metabolism in trained versus untrained individuals and revealed that greater turnover occurs in untrained participants. Thus, the requirements of leucine may change as training status progresses. Certainly, future work is needed to explore this possibility.

Readers of our paper are cautioned to closely consider some key limitations that exist within the present study. First, while consistent with other training studies of this nature $[12,38,39]$, the duration of the supplementation and resistance training program in the present study was only 8 weeks. In this respect, it is acknowledged that a longer investigation may have allowed for a greater difference in the protein groups, which may have led to a statistically significant difference being identified between the groups. Second, the number of our subjects, while suitable to yield small between-group effects was still low for this study design. As a result, we may not have had enough power to appropriately identify between-group outcomes. However, our overall changes in fat-free mass accretion were similar in magnitude to those reported by Cermak et al. [40] in a meta-analysis of studies investigating the impact of protein supplementation on resistance training, but are smaller than other studies that were longer in duration $[27,41]$. As such, readers are cautioned from drawing straight-line conclusions that rice and whey protein are equal until longer and larger investigations have been completed. Some may view our lack of direct exercise training supervision as a limitation, as previous work has indicated that strength increases are greater when direct supervision occurs [42]. However, the impact of supervision on body composition changes remains undetermined. Regardless, while participants in the present study were not directly supervised, they were required to submit daily photos after completing each workout and submit a separate photo of their daily supplementation consumption. In addition, participants were required to log their nutrition, and every 2 weeks returned their empty sachets and received a new supply of their assigned supplements. Further, these visits were used to counsel participants on meeting their assigned nutritional goals and reviewed the loads they were using as part of their exercise program. As seen in Table 2, participants were generally able to achieve appropriate levels of energy (29.3-30.8 kcal/ $\mathrm{kg}$ body mass) and protein (1.6-1.75 g/ $\mathrm{kg}$ body mass) to facilitate fat-free mass accretion. Unfortunately, we did not measure body mass at these two-week check points, which would have 
allowed for bi-weekly calculation of relative nutritional intake, but calculations using baseline body mass levels allow for suitable insight. Additionally, the raw (non-normalized) nutritional information can be found in Table 2.

A key strength to this investigation was the randomized, double-blind approach with an isocaloric and isonitrogenous protein control group. Additionally, to minimize the acute increases in strength commonly observed when someone begins a new exercise program, all participants completed eight workouts (four upper-body, four lowerbody) prior to beginning their assigned supplement. As previously discussed, good compliance was accomplished or maintained for our prescribed nutritional (See Table 2) and resistance training regimens. Future research should explore longer investigations that incorporate more direct measures of body composition (muscle thickness and fiber cross-sectional area via skeletal muscle biopsy and ultrasound) and skeletal muscle protein turnover. In conclusion, the current investigation compared the impact of consuming 24-g doses of rice and whey protein concentrate while resistance training for 8 weeks. It was revealed that statistically similar changes in body composition changes and exercise performance were observed between the protein groups. While our results are limited by our study duration and sample size, initial evidence provided by this investigation suggests that supplementing with whey or rice protein concentrate may yield similar changes to body composition and performance over an eight-week period in healthy, resistance-trained men.

\section{Acknowledgements}

The authors would like to thank the study participants for their commitment to this study protocol. The authors are particularly appreciative of the thirdparty screening of all supplements for known contaminant and banned substances completed by LGC Science, Inc. at no charge (Lexington, KY; www.lgcgroup.com)

\section{Authors' contributions}

Designed Study: CMK, RJ, MP and ARJ. Data Collection: JMM, JCB, BSC, RS, PSH, HAZ, and RAS. Analyzed Data: CMK, PSH, and RAS. Prepared Initial Draft: CMK, JMM, and KMR. Approved Final Version: All Authors.

\section{Authors' information}

CMK is an Associate Professor of Exercise Science and Director of the Exercise and Performance Nutrition Laboratory (www.lindenwood.edu/epnl/) in the School of Health Sciences at Lindenwood University. PSH is affiliated with the Energy Balance and Body Composition Laboratory at Texas Tech University. HAZ is affiliated with Towson University, ARJ is the Director of Sports Medicine Research for the Mayo Clinic Health System in Onalaska, WI. JMM, JCB, BSC, and RS are affiliated with the Exercise and Performance Nutrition Laboratory at Lindenwood University. RJ and MP are managing members of Increnovo, LLC (Milwaukee, WI).

\section{Funding}

This research was funded by an unrestricted grant from Axiom Foods, CA. The sponsor played no role in collecting the data, analyzing the data, interpreting the results, or preparing the manuscript.

\section{Availability of data and materials}

Please contact corresponding author for additional data. Only blinded, deidentified data may be provided upon request with an appropriate and substantiated justification for any such request.

\section{Ethics approval and consent to participate}

Ethical approval was obtained from the Lindenwood University IRB (protocol \# 1242220-1, approval date: 5/22/2018). All study participants were required to sign and provide their informed consent prior to any data collection.

Consent for publication

Not applicable.

\section{Competing interests}

$\mathrm{RJ}$ is an inventor of patent WO2014138305 (US 9,820,504) and has not been involved in the data collection and analysis or writing the manuscript. All other authors declare no competing interests. All other authors declare no conflicts of interest.

\section{Author details}

${ }^{1}$ Exercise and Performance Nutrition Laboratory, School of Health Sciences, Lindenwood University, 209 S. Kingshighway, St. Charles, MO 63301, USA. ${ }^{2}$ Energy Balance and Body Composition Laboratory, Department of Kinesiology \& Sport Management, Texas Tech University, Lubbock, TX, USA. ${ }^{3}$ Department of Kinesiology, Towson University, Towson, MD, USA. ${ }^{4}$ Sports Medicine, Mayo Clinic Health System, Onalaska, WI, USA. ${ }^{5}$ ncrenovo LLC, Milwaukee, WI, USA.

Received: 10 July 2020 Accepted: 20 November 2020

Published online: 01 December 2020

\section{References}

1. Trumbo P, Schlicker S, Yates AA, Poos M. Food, and nutrition Board of the Institute of medicine TNA. Dietary reference intakes for energy, carbohydrate, fiber, fat, fatty acids, cholesterol, protein and amino acids. J Am Diet Assoc. 2002;102(11):1621-30.

2. Thomas DT, Erdman KA, Burke LM. Position of the academy of nutrition and dietetics, dietitians of Canada, and the american college of sports medicine: nutrition and athletic performance. J Acad Nutr Diet. 2016;116(3):501-28.

3. Jager R, Kerksick CM, Campbell BI, Cribb PJ, Wells SD, Skwiat TM, Purpura M, Ziegenfuss TN, Ferrando AA, Arent SM, Smith-Ryan AE, Stout JR, Arciero PJ, Ormsbee MJ, Taylor LW, Wilborn CD, Kalman DS, Kreider RB, Willoughby DS, Hoffman JR, Krzykowski JL, Antonio J. International society of sports nutrition position stand: Protein and exercise. J Int Soc Sports Nutr. 2017;14:20.

4. Biolo G, Maggi SP, Williams BD, Tipton KD, Wolfe RR. Increased rates of muscle protein turnover and amino acid transport after resistance exercise in humans. Am J Phys. 1995;268(3 Pt 1):E514-20.

5. Trommelen J, Betz MW, Van Loon LJC. The muscle protein synthetic response to meal ingestion following resistance-type exercise. Sports Med. 2019;49(2):185-97.

6. Moore DR. Maximizing post-exercise anabolism: The case for relative protein intakes. Front Nutr. 2019;6:147.

7. Tipton KD, Gurkin BE, Matin S, Wolfe RR. Nonessential amino acids are not necessary to stimulate net muscle protein synthesis in healthy volunteers. J Nutr Biochem. 1999;10(2):89-95.

8. Volpi E, Kobayashi H, Sheffield-Moore M, Mittendorfer B, Wolfe RR. Essential amino acids are primarily responsible for the amino acid stimulation of muscle protein anabolism in healthy elderly adults. Am J Clin Nutr. 2003; 78(2):250-8.

9. Gorissen SHM, Crombag JJR, Senden JMG, WaH W, Bierau J, Verdijk LB, LC VL. Protein content and amino acid composition of commercially available plant-based protein isolates. Amino Acids. 2018;50(12):1685-95.

10. Churchward-Venne TA, Burd NA, Mitchell CJ, West DW, Philp A, Marcotte GR, Baker SK, Baar K, Phillips SM. Supplementation of a suboptimal protein dose with leucine or essential amino acids: effects on myofibrillar protein synthesis at rest and following resistance exercise in men. J Physiol. 2012; 590(Pt 11):2751-65.

11. Norton LE, Layman DK, Bunpo P, Anthony TG, Brana DV, Garlick PJ. The leucine content of a complete meal directs peak activation but not duration of skeletal muscle protein synthesis and mammalian target of rapamycin signaling in rats. J Nutr. 2009;139(6):1103-9.

12. Joy JM, Lowery RP, Wilson JM, Purpura M, De Souza EO, Wilson SM, Kalman DS, Dudeck JE, Jager R. The effects of 8 weeks of whey or rice protein supplementation on body composition and exercise performance. Nutrition J. 2013;12:86. 
13. Escobar KA, Mclain TA, Kerksick CM. Protein applications in sports nutrition part ii: timing and protein patterns, fat-free mass accretion, and fat loss. Strength Cond J. 2015;37(3):22-34.

14. Mclain TA, Escobar KA, Kerksick CM. Protein applications in sports nutrition part i: requirements, quality, source, and optimal dose. Strength Cond J. 2015:37(2):61-71.

15. Trommelen J, Kouw IWK, Holwerda AM, Snijders T, Halson SL, Rollo I, Verdijk LB, Van Loon LJC. Presleep dietary protein-derived amino acids are incorporated in myofibrillar protein during postexercise overnight recovery. Am J Physiol Endocrinol Metab. 2018;314(5):E457-67.

16. Snijders T, Res PT, Smeets JS, Van Vliet S, Van Kranenburg J, Maase K, Kies $A K$, Verdijk LB, Van Loon LJ. Protein ingestion before sleep increases muscle mass and strength gains during prolonged resistance-type exercise training in healthy young men. J Nutr. 2015;145(6):1178-84.

17. Purpura M, Lowery RP, Joy JM, De Souza EO, Kalman D. A comparison of blood amino acid concentrations following ingestion of rice and whey protein isolate: a double-blind, crossover study. J Nutr Health Sci. 2014;1(3):306.

18. Kerksick CM, Wilborn CD, Roberts MD, Smith-Ryan A, Kleiner SM, Jager R, Collins R, Cooke M, Davis JN, Galvan E, Greenwood M, Lowery LM, Wildman $\mathrm{R}$, Antonio J, Kreider RB. Issn exercise \& sports nutrition review update: research \& recommendations. J Int Soc Sports Nutr. 2018:15(1):38.

19. Moon JR, Tobkin SE, Roberts MD, Dalbo VJ, Kerksick CM, Bemben MG, Cramer JT, Stout JR. Total body water estimations in healthy men and women using bioimpedance spectroscopy: A deuterium oxide comparison. Nutr Metab (Lond). 2008;5:7.

20. Kerksick CM, Wilborn CD, Campbell BI, Roberts MD, Rasmussen CJ, Greenwood M, Kreider RB. Early-phase adaptations to a split-body, linear periodization resistance training program in college-aged and middle-aged men. J Strength Cond Res. 2009;23(3):962-71.

21. Mann JB, Thyfault JP, Ivey PA, Sayers SP. The effect of autoregulatory progressive resistance exercise vs. linear periodization on strength improvement in college athletes. J Strength Cond Res. 2010;24(7):1718-23.

22. Harris J and Benedict F: A biometric study of basal metabolism in man. Washington,: Carnegie Institution of Washington; 1919(Series Editor): Carnegie institution of washington publication.

23. Mifflin MD, St Jeor ST, Hill LA, Scott BJ, Daugherty SA, Koh YO. A new predictive equation for resting energy expenditure in healthy individuals. Am J Clin Nutr. 1990;51(2):241-7.

24. Phillips SM, Tipton KD, Aarsland A, Wolf SE, Wolfe RR. Mixed muscle protein synthesis and breakdown after resistance exercise in humans. Am J Phys. 1997;273(1 Pt 1):E99-107.

25. Tipton KD, Ferrando AA, Phillips SM, Doyle D Jr, Wolfe RR. Postexercise net protein synthesis in human muscle from orally administered amino acids. Am J Phys. 1999;276(4 Pt 1):E628-34.

26. Babault N, Paizis C, Deley G, Guerin-Deremaux L, Saniez MH, Lefranc-Millot C, Allaert FA. Pea proteins oral supplementation promotes muscle thickness gains during resistance training: A double-blind, randomized, placebocontrolled clinical trial vs. Whey protein. J Int Soc Sports Nutr. 2015;12(1):3.

27. Hartman JW, Tang JE, Wilkinson SB, Tarnopolsky MA, Lawrence RL, Fullerton AV, Phillips SM. Consumption of fat-free fluid milk after resistance exercise promotes greater lean mass accretion than does consumption of soy or carbohydrate in young, novice, male weightlifters. Am J Clin Nutr. 2007; 86(2):373-81.

28. Wilkinson SB, Tarnopolsky MA, Macdonald MJ, Macdonald JR, Armstrong D, Phillips SM. Consumption of fluid skim milk promotes greater muscle protein accretion after resistance exercise than does consumption of an isonitrogenous and isoenergetic soy-protein beverage. Am J Clin Nutr. 2007;85(4):1031-40.

29. Thomson RL, Brinkworth GD, Noakes M, Buckley JD. Muscle strength gains during resistance exercise training are attenuated with soy compared with dairy or usual protein intake in older adults: a randomized controlled trial. Clin Nutr. 2016;35(1):27-33

30. Candow DG, Burke NC, Smith-Palmer T, Burke DG. Effect of whey and soy protein supplementation combined with resistance training in young adults. Int J Sport Nutr Exerc Metab. 2006;16(3):233-44.

31. Maltais ML, Ladouceur JP, Dionne IJ. The effect of resistance training and different sources of postexercise protein supplementation on muscle mass and physical capacity in sarcopenic elderly men. J Strength Cond Res. 2016; 30(6):1680-7.

32. Deane CS, Bass JJ, Crossland H, Phillips BE, Atherton PJ. Animal, plant, collagen and blended dietary proteins: Effects on musculoskeletal outcomes. Nutrients. 2020;12:9.
33. Drummond MJ, Dreyer HC, Fry CS, Glynn EL, Rasmussen BB. Nutritional and contractile regulation of human skeletal muscle protein synthesis and mtorc1 signaling. J Appl Physiol. 2009;106(4):1374-84.

34. Drummond MJ, Rasmussen BB. Leucine-enriched nutrients and the regulation of mammalian target of rapamycin signalling and human skeletal muscle protein synthesis. Curr Opin Clin Nutr Metab Care. 2008;11(3):222-6.

35. Norton LE, Wilson GJ, Layman DK, Moulton CJ, Garlick PJ. Leucine content of dietary proteins is a determinant of postprandial skeletal muscle protein synthesis in adult rats. Nutr Metab (Lond). 2012;9(1):67.

36. Moore DR, Robinson MJ, Fry JL, Tang JE, Glover El, Wilkinson SB, Prior T, Tarnopolsky MA, Phillips SM. Ingested protein dose response of muscle and albumin protein synthesis after resistance exercise in young men. Am J Clin Nutr. 2009;89(1):161-8.

37. Phillips SM, Tipton KD, Ferrando AA, Wolfe RR. Resistance training reduces the acute exercise-induced increase in muscle protein turnover. Am J Phys. 1999;276(1 Pt 1):E118-24.

38. Kerksick CM, Rasmussen CJ, Lancaster SL, Magu B, Smith P, Melton C, Greenwood M, Almada AL, Earnest CP, Kreider RB. The effects of protein and amino acid supplementation on performance and training adaptations during ten weeks of resistance training. J Strength Cond Res. 2006;20(3): 643-53.

39. Brown EC, Disilvestro RA, Babaknia A, Devor ST. Soy versus whey protein bars: Effects on exercise training impact on lean body mass and antioxidant status. Nutrition J. 2004;3:22.

40. Cermak NM, Res PT, De Groot LC, Saris WH, Van Loon LJ. Protein supplementation augments the adaptive response of skeletal muscle to resistance-type exercise training: a meta-analysis. Am J Clin Nutr. 2012;96(6): 1454-64.

41. Kerksick CM, Rasmussen C, Lancaster S, Starks M, Smith P, Melton C, Greenwood M, Almada A, Kreider R. Impact of differing protein sources and a creatine containing nutritional formula after 12 weeks of resistance training. Nutrition. 2007;23(9):647-56.

42. Mazzetti SA, Kraemer WJ, Volek JS, Duncan ND, Ratamess NA, Gomez AL, Newton RU, Hakkinen K, Fleck SJ. The influence of direct supervision of resistance training on strength performance. Med Sci Sports Exerc. 2000; 32(6):1175-84

\section{Publisher's Note}

Springer Nature remains neutral with regard to jurisdictional claims in published maps and institutional affiliations.
Ready to submit your research? Choose BMC and benefit from:

- fast, convenient online submission

- thorough peer review by experienced researchers in your field

- rapid publication on acceptance

- support for research data, including large and complex data types

- gold Open Access which fosters wider collaboration and increased citations

- maximum visibility for your research: over $100 \mathrm{M}$ website views per year

At $\mathrm{BMC}$, research is always in progress.

Learn more biomedcentral.com/submissions 